\title{
Faktor-Faktor yang Mempengaruhi Produksi dan Strategi Pengembangan Usahatani Bawang Putih di Kecamatan Miomaffo Barat Kabupaten Timor Tengah Utara
}

\author{
Marsianus Falo ${ }^{\mathrm{a}}$, Simon Juan Kune ${ }^{\mathrm{b}}$, Adeline Norawati Hutapea ${ }^{\mathrm{c}}$, Origenes Kapitan ${ }^{\mathrm{d}}$ \\ ${ }^{a}$ Fakultas Pertanian, Universitas Timor, Kefamenanu, Indonesia. \\ ${ }^{b}$ Fakultas Pertanian, Universitas Timor, Kefamenanu, Indonesia. \\ ${ }^{c}$ Fakultas Pertanian, Universitas Timor, Kefamenanu, Indonesia. \\ ${ }^{d}$ Fakultas Pertanian, Universitas Timor, Kefamenanu, Indonesia
}

\section{Article Info}

Article history:

Received 14 Oktober 2016

Received in revised form 19 Oktober 2016

Accepted 22 Oktober 2016

\section{Keywords:}

Faktor Produksi

Strategi Pengembangan

Usahatani Bawang Putih

Miomaffo Bara

\section{Abstrak}

Penelitian ini bertujuan untuk 1) mendeskripsikan keragaan usahatani bawang putih; 2) menganalisis kandungan unsur metabolid sekunder; 3) menganalisis faktor-faktor yang berpengaruh terhadap produksi usahatani bawang putih; 4) menganalisis pendapatan yang dipeoleh petani dari usahatani bawang putih, dan; 5) mengetahui startegi pengembangan usahatani bawang putih. Metode yang dugunakan adalah survei dan eksperimen laboratorium. Analisa data menggunakan analisis FTIR dan GC-MS, Analisis Cobb Douglass, analisis pendapatan dan Analisis SWOT. Hasilnya keragaan usahatani meliputi pengolahan lahan, persiapan bibit, penanaman, pemeliharaan, panen, pasca panen dan pemasaran. Unsur metabolid sekunder yang terdapat dalam bawang putih adalah adsiri, faktor-faktor yang berpengaruh terhadap produksi antara lain lahan, benih, tenaga kerja, pengalaman, dan pendidikan. Pendapatan yang diperoleh sebesa 534.429.503/musim tanam. Strategi pengembangannya adalah 1) strategi SO : kekuatan yang dimiliki adalah letak lahan yang strategis, kerjasama dalam kelompok, iklim yang mendukung dan pengalaman dan peluangnya dukungan dari PEMDA, permintaan pasar yang selalu ada, eban merupakan sentral/pusat produksi bawang putih di wilayah TTU; 2) strategi WO : meningkatkan modal berusahatani bawang putih, kurang promosi, sistim pemasaran dan penguasaan teknik budidaya yang masih rendah; 3) Strategi ST : kekuatan yang ada adalah letak lahan memiliki sendiri, kerja sama dalam kelompok, iklim yang mendukung dan pengalaman yang telah dimiliki; 4) Strategi WT : meningkatkan modal yang di miliki petani untuk dapat bersaing deengan usahatani bawang putih sejenis lainnya dari luar daerah Eban dan meningkatkan promosi untuk jangkauan pemasaran yang lebih luas lagi. (O2016 dipublikasikan oleh Agrimor.

\section{Pendahuluan}

Bawang putih merupakan tanaman hortikultura yang banyak dibutuhkan terutama dalam peranannya sebagai penambah citarasa makanan dan sebagai bumbu masak berbagai macam makanan, selain itu bawang putih juga sering digunakan sebagai obat - obatan untuk penyakit tertentu seperti tekanan darah tinggi, sakit kepala dan menurunkan kadar kolesterol. Oleh karena itu komoditi ini hendaknya terus dikembangkan, baik dari luasan areal tanam, kuantitas maupun kualitas.

Bawang putih mengandung minyak atsiri yang bermanfaat sebagai anti bakteri dan anti septik, bawang putih juga mengandung allicin dan aliin yang bermanfaat sebagai daya anti kolesterol untuk, mencegah penyakit jantung koroner, tekanan darah tinggi dll. Selain itu Pada umbi bawang putih mengandung senyawa kimia yang cukup banyak, diantaranya : 1. Kalsium yang memiliki sifat menenangkan sehingga cocok sebagai pencegah hipertensi, 2 . Saltivine yang bermanfaat sebagai mempercepat pertumbuhan sel dan jaringan serta merangsang susunan sel syaraf, 3. Diallysulfide, alilpropil-disulfida : ant cacing, 4. Belerang, 5. Protein, 6. Lemak, 7. Fosfor, 8. Besi dan 9. Vitamin A B1 dan C. (Rasyid, 2004).

Pemerintah Kabupaten Timor Tengah Utara terus mengupayakan daerahdaerah yang berpontensi untuk pengembangan bawang putih. Salah satu daerah yang berpotensi adalah kecamatan Miomaffo Barat, cocok untuk pertumbuhan tanaman bawang putih (ketinggian $700-1100 \mathrm{M}$ dpl ( diatas permukaan laut) dengan suhu rata-rata $20^{\circ}-25^{\circ} \mathrm{C}$ dan memiliki curah hujan rata-rata $1200-2400$ mm per tahun serta menghendaki tekstur tanah yang gembur dan subur) dan juga bagi masyarakatnya usahatani bawang putih telah dilakukan secara turun temurun.

Produksi bawang putih di kecamatan Miomafo Barat produksinya sangat berfluktuasi disetiap tahunnya, data 5 tahun terakhir (BPS TTU, 2015) hal in penyebabnya antara lain keadaan iklim khususnya curah hujan yang tidak menentu, luasan areal tanam dan luas panen yang berdampak pada jumlah produksi yang diperoleh. Situasi ini kemudian berakibat pada produksi bawang putih lokal belum mampu memenuhi permintaan bawang putih masyarakat di kabupaten ini sehinggaharus diimport dari luar (survei awal).

Persoalan diatas diperparah lagi dengan kualitas dari bawang putih lokal itu sendiri, karena berdasarkan observasi yang dilakukan untuk mengetahu preferensi masyarakat terhadap bawang putih di pasar baru dan pasar lama Kefamenanu antara bawang lokal dan bawang import ; ternyata minat masyarakat terhadap bawang putih lokal dan bawang putih import itu sama, dimana bawang putih lokal memiliki aroma dan rasa yang lebih unik dibanding bawang putih impor, namun memiliki ukuran umbi yang jauh lebih kecil dar bawang putih impor, dengan demikian akan menyulitkan disaat proses pengupasan.

Hal diatas menunjukan bahwa Pendapatan petani dapat meningkat jika dilakukan pengembangan usahatani bawang putih yang bersifat komersia dengan memperhatikan starategi-strategi pengembangan mulai dari proses pembudidayaan hingga proses pemasaran guna meningkatkan pendapatan petani Dalam penentuan strategi tentunya petani dituntut untuk memperhatikan faktor external dan internal yang terkait.

Tujuan dari penelitian ini adalah 1) mengetahui keragaan usahatani bawang putih di Kecamatan Miomaffo Barat Kabupaten TTU; 2) mengetahui kandungan unsur metabolid sekunder dalam tanaman bawang putih; 3) mengetahui faktorfaktor yang berpengaruh terhadap produksi usahatani bawang putih; 4) mengetahui pendapatan yang dipeoleh petani dari usahatani bawang putih, dan; 5) mengetahui startegi pengembangan usahatani bawang putih.

\section{Metode}

Penelitian dilaksanakan di Kecamatan Miomaffo Barat Kabupaten Timor Tengah Utara pada bulan Mei hingga Oktober 2016. Penentuan responden yang dilakukan secara acak sederhana yaitu dengan mengambil 25\% dari setiap desa dimana untuk Desa Fatuneno yang menjadi responden adalah 25\% dari $460 \mathrm{KK}$ yaitu $115 \mathrm{KK}$, dan Desa Noepesu 25\% dari $423 \mathrm{KK}$ yaitu 105 . Total responden yang diambil yaitu 220 KK. Penelitian ini menggunakan metode survei. Data yang dikumpulkan terdiri atas dua macam yaitu data primer dan data sekunder. Data yang diperoleh dikumpulkan kemudian ditabulasi dan dianalisis berdasarkan tujuan penelitian yaitu

1. Untuk menjawab tujuan pertama, dianalisis dengan pendekatan deskriptif kualitatif, yang dilakukan untuk memperoleh informasi tentang usahatani bawang putih.

2. Untuk menjawab tujuan ke dua akan dilakukan uji laboratorium terhadap kandungan bawang putih yang berasal dari petani bawang di Miomafo Barat

3. Untuk menjawab tujuan ke tiga akan dilakukan analisis statistik dengan menggunkan program SPSS. Secara matematis dapat ditulis ; Ln Y $=\ln b_{0}+$ $b_{1} \ln X_{1}+b_{2} \ln X_{2}+b_{3} \ln X_{3}+b_{4} \ln X_{4}+b_{5} \ln X_{5}+b_{6} \ln X_{6}+b_{7} \ln X_{7}+e$

4. Untuk menjawab tujuan ke empat dilakukan perhitungan pendapatan usahatani bawang putih dengan rumus : Soekartawi (1995) yaitu : $\mathrm{Pd}=\mathrm{R}$ TC Dimana : $\mathrm{Pd}=$ Pendapatan TR $=$ Total Penerimaan TC $=$ Total Biaya

5. Untuk menjawab tujuan ke empat, dianalisis dengan alat analisis SWOT yaitu suatu analisis mengenai faktor Internal usaha berupa kekuatan (Strengths), kelemahan (Weaknesses), dan faktor eksternal usaha berupa peluang (Opportunities) dan tantangan (Threats) (Rangkuti. 2003).

\section{Hasil dan Pembahasan}

3.1 Keragaan Usahatani Bawang Putih di Kecamatan Miomaffo Barat Kegiatan usahatani bawang putih di Desa Fatuneno dan Desa Noepesu dilakukan dengan beberapa proses yakni: Pengolahan Lahan, persiapan bibit, Penanaman, Pemeliharaan, panen, Pasca Panen dan pemasaran.

a. Pengolahan Lahan

Proses pengolahan ini diawali dengan pembersihan, Dalam pengolahan lahan, masyarakat di Desa Fatuneno dan Desa Noepesu masih menggunakan sistim tradisional, alat pertanian yang digunakan dalam proses pengolahan lahan antara lain parang, pacul, linggis, tajak, karung dan sabit.

b. Persiapan bibit

Bibit yang digunakan oleh petani diperoleh dari hasil panen musim tanam sebelumnya dengan cara memilih umbi yang berkulitas.

c. Penanaman

Penanaman bawang putih pada awal bulan Mei dengan tujuan agar bawang putih yang telah ditanam tidak digenangi air hujan dan terhindar dari kabut yang berlebihan karena jika curah hujan tinggi maka bawang putih akan terserang penyakit yang mengakibatkan bercak-bercak putih dan akhirnya mati.

d. Pemeliharaan

Pemliharaan yang dilakukan oleh petani di Desa Fatuneneo dan Desa Noepesu dapat dilihat sebagai berikut:

Penyiangan

Sekitar 2 minggu, maka selanjutnya petani melakukan pemeliharaan dengan cara, membersihkan tumbuhan pengganggu berupa rerumputan dan tunas baru pada pohon-pohon yang ditebang sebelumnya. 
e. Panen dan Pasca Panen

- Panen.

Sesuai hasil penelitian, panen dilakukan ketika berumur 3 bahkan 3,5 bulan terhitung dari saat penanaman.

- Pasca panen

Setelah dipanen bawang putih akan dijemur dengan batangnya sampai kering. Proses penjemuran ini dilakukan agar umbi yang baru dipanen mengeras sehingga terhindar dari kebusukan.

- Pemasaran

Hasil produksi bawang putih dari masing-masing petani berbeda - beda hal ini terjadi karena luas lahan usahatani bawang putih juga berbedabeda, sehingga berpengaruh pada pendapatan petani juga berbeda. Selain itu juga salah satu faktor yang membedakan pendapatan petani adalah harga yang tidak sama, hal ini terjdi karena belum ada kesamaan harga antara petani yang satu dengan petani yang lainnya. Harga penjualan bawang putih di Desa Fatuneno dan Desa Noepesu berkisar antara Rp. 20.000 sampai Rp.45.000 per kilogram.

\subsection{Kandungan Metabolid Sekunder} berikut

Prosedur kerja analisis minyak atsiri bawang putih asal Eban adalah sebagai

1. Perlakuan bahan baku bawang putih diawali dengan penyiapan umbi bawang putih. Tahap penyiapan meliputi pembersihan kulit ari umbi bawang putih. Umbi yang telah bersih ditimbang. Umbi kemudian digerus dalam ruangan bersuhu rendah.

2. Selanjutnya dilakukan penyulingan air.

3. Filtrat penyulingan ditampung pada corong pisah dan didiamkan selama 24 jam.

4. Dilakukan pemisahan minyak dari air

Umbi yang digunakan dalam penelitian sebanyak $4.5 \mathrm{~kg}$. Rendemen minyak yang diperoleh sebanyak $4.5 \mathrm{~mL}$. Rendemen minyak yang diperoleh adalah $1 \%$ (v/b). Hasil ekstraksi diperoleh minyak atsiri bawang putih sebanyak 4,5 mL. Hasil yang sedikit ini diakibatkan oleh mudah menguapnya senyawa-senyawa penyusun minyak bawang putih baik selama proses persiapan sampel maupun selama proses penyulingan. Menurut Harborne (1996), minyak atsiri pada jaringan tanaman berkisar 1-2\% dari bobot bahan baku, sehingga minyak atsiri yang diharapkan adalah berkisar 6-9 mL. Minyak atsiri yang diperoleh mempunyai warna bening, berbau khas menyengat, dan mudah menguap. Ini menunjukkan bahwa sifat minyak atsiri yang diperoleh sama seperti minyak atsiri pada umumnya.

\subsection{Analisis Cobb-Douglass}

Fungsi Cobb - Douglas digunakan untuk menguji pengaruh antara variabel independen terhadap variabel dependen (produksi bawang putih). Dari angka korelasi kemudian dilakukan model pendugaan dengan cara regresi. Hasil dari fungsi cobb - douglas adalah $\operatorname{LnY}=\operatorname{Ln}$ h0.628 $+328 \operatorname{LnX} X_{1}+468 \operatorname{Ln} X_{2}-063 \operatorname{Ln} X_{3}+$ $020 \operatorname{Ln} X_{4}+025 \operatorname{Ln} X_{5}$

\subsection{Analisis Uji Keragaman (Uji F)}

Uji $\mathrm{F}$ dilakukan untuk mengetahui apakah variabel-variabel independen (luas lahan, benih, tenaga kerja, pengalaman, pendidikan formal) secara bersamasama mempengaruhi variabel dependen(produksi usahatani bawang putih) dengan membandingkan rata-rata kuadrat regresi dengan rata-rata kuadarat residu dan hasilnya dapat dilihat dalam Tabel 1

Tabel 1. AnalisisF $F_{\text {hitung }}$

\begin{tabular}{lccccc}
\hline \multicolumn{1}{c}{ Model } & $\begin{array}{r}\text { Jumlah } \\
\text { kuadrat }\end{array}$ & Df & $\begin{array}{c}\text { Jumlah } \\
\text { rerata }\end{array}$ & F $_{\text {hitung }}$ & Ftabel \\
\hline 1 Regression & 70.793 & 5 & 14.159 & 146.723 & $2.54 \%$ \\
Residual & 24.993 & 259 & .096 & & \\
Total & 95.786 & 264 & & & \\
\hline
\end{tabular}

Sumber: Data Primer Diolah, 2016

Berdasarkan analisis regresi Tabel 1. dapat dilihat bahwa nilai $F_{\text {hitung }}$ (146.723) > dari nilai $\mathrm{F}_{\text {tabel }}$ (2.54). Dengan demikian dapat disimpulkan secara statistik dapat dibuktikan bahwa semua variabel independen luas lahan, benih, tenaga keja, pengalaman, dan pendidikan secara bersama-sama (simultan) berpengaruh terhadap variabel hasil produktivitas bawang putih.
3.5 Analisis Koefisien Regresi (Uji t)

Analisis koefisien regresi dapat dilihat pada Tabel 2.

Tabel 2. Koefisien Regresi.

\begin{tabular}{cccc}
\hline \hline Koefisien Regresi & & & \\
\hline Model & Beta & t-hitung & t-tabel \\
\hline (constant) & 0.628 & 1.041 & \\
lahan & 0.328 & 2.186 & \\
benih & 0.468 & 2.116 & $1.635 \%$ \\
tenaga kerja & 0.063 & 0.261 & \\
pengalaman & 0.020 & 0.602 & \\
pendidikan & 0.025 & 0.726 & \\
\hline \hline
\end{tabular}

Sumber: Data Primer Diolah, 2016

1. Pengaruh Luas Lahan Terhadap Produktivitas bawang putih

Berdasarkan analisis data, diketahui $t_{\text {hitung }}$ luas lahan (2.186) $>t_{\text {tabel }}(1.63)$ dengan demikian Ho ditolak dan Ha diterima. Hal ini berarti makin besar luas lahan yang digarap untuk berusahatani bawang putih maka makin meningkatkan produksi bawang putih. Nilai koefisien Regresi Luas Lahan (X1) sebesar 0.328 artinya setiap penambahan 1 (satu) persen luas lahan akan meningkatkan produksi sebesar 0.628 persen dengan asumsi variabel lain dianggap tetap.

2. Pengaruh benih terhadap produktivitas bawang putih

Berdasarkan analisis data, diketahui $t_{\text {hitung }}$ benih $(2.116)>t_{\text {tabel }}(1.63)$ Hal disebakan karena petani ditempat penelitian selalu menggunakan benih yang unggul. Nilai koefisien regresi benih (X2) sebesar 0.468 menunjukkan bahwa tiap penambahan 1 (satu) persen jumlah benih akan meningkatkan produksi sebesar 0.468 persen dengan asumsi variabel lain dianggap tetap.

3. Pengaruh tenaga kerja (X3) terhadap produktivitas bawang putih (Y)

Berdasarkan analisis data, diketahui $\mathrm{t}_{\text {hitung }}$ tenaga kerja $(0,261)<\mathrm{t}_{\text {tabel }}(1.63)$ hal ini karena tenaga kerja yang digunakan berkeja dengan baik sehingga dapat membantu dalam meningkatkan hasil produksi. Nilai Koefisien regresi sebesar 0.63 yang menunjukkan apabila jumlah tenaga kerja bertambah $1 \mathrm{HOK}$ akan meningkatkan produksi sebesar 0.63 persen dengan asumsi variabel lain dianggap tetap.

4. Pengaruh pengalaman (X4) terhadap produktivitas bawang putih (Y)

Berdasarkan analisis data, diketahui $\mathrm{t}_{\text {hitung }}$ pengalaman $(0,620)<\mathrm{t}_{\text {tabel }}(1.63)$ Berdasarkan hasil uji statistik ini dapat disimpulkan, bahwa pengalaman secara parsial tidak berpengaruh secara nyata terhadap hasil produktivitas bawang putih karena petani di daerah penelitian tidak belajar dari pengalaman yang mereka miliki sebelumnya. Nilai koefisien regresi pengalaman (X4) sebesar 0,20 menunjukan bahwa tiap penambahan 1 (satu) persen tingkat pengalaman akan meningkatkan produksi sebesar 0,20 persen dengan asumsi variable lain dianggap tetap.

5. Pengaruh pendidikan (X5) terhadap produktivitas bawang putih (Y)

Berdasarkan analisis data, diketahui $\mathrm{t}_{\text {hitung }}$ pendidikan $(0,726)<\mathrm{t}_{\text {tabel }}(1.63)$ Berdasarkan hasil uji statistik ini dapat disimpulkan, bahwa pendidikan formal secara parsial tidak berpengaruh secara signifikan terhadap hasil produktivitas bawang putih. Pendidikan formal tidak berpengaruh nyata terhadap produksi bawang putih karena tingkat pendidikan petani di daerah penelitian masih rendah. Hal ini diketahui dari presentase tingkat pendidikan responden terbanyak berada pada tingkat pendidikan sekolah dasar sehingga menyebabkan rendahnya produktifitas tenaga kerja dan manajemen di sector pertanian. Nilai koefisien regresi pendidikan (X5) sebesar 0.25 menunjukkan bahwa tiap penambahan 1 (satu) persen tingkat pendidikan akan meningkatkan produksi sebesar 0.25 persen dengan asumsi variabel lain dianggap tetap.

\subsection{Analisis Uji Koefisien Determinasi (R2)}

Koefisien determinasi adalah besarnya keragaman variabel terikat $(\mathrm{Y})$ yang mampu dijelaskan oleh seluruh variabel bebas $\left(\mathrm{X}_{\mathrm{i}}\right)$ dalam model Nilai koefisien determinasi merupakan perbandingan antara jumlah kuadrat regresi dengan kuadrat total dapat dilihat pada Tabel 3.

Tabel 3. Analisis Koefisien Determinasi $\left(\mathrm{R}^{2}\right.$

\begin{tabular}{ccccc}
\hline Model & $\mathrm{R}$ & $\begin{array}{c}\mathrm{R} \\
\text { Square }\end{array}$ & Adjusted R Square & Std. Error of the Estimate \\
\hline 1 & $.886^{\mathrm{a}}$ & .784 & .880 & .07286 \\
\hline
\end{tabular}

Sumber: Data Primer Diolah, 2016

Dari Tabel 3. dapat dikatakan bahwa dalam model variabel independen (luas lahan, benih, tenaga kerja, pengalaman, dan pendidikan) secara bersamasama berpengaruh terhadap variabel dependen(produksi usahatani bawang putih) sebesar 78,4\% sisanya yaitu sebesar $21.6 \%$ dipengaruihi oleh faktor lain yang tidak diuji dalam penelitian ini.

\subsection{Analisis Pendapatan Usahatani}

Analisis pendapatan dilakukan terhadapa biaya, penerimaan serta keuntungan kegiatan produksi bawang putih mulai dari pengolahan lahan hingga pemasaran yang dilakukan dalam satu tahun produksi (satu musim tanam). Analisis pendapatan digunakan untuk mengetahui besarnya penerimaan dan keuntungan yang diperoleh dari hasil penjualan bawang putih. Berdasarkan olahan hasil penelitian diketahui bahwa pendapatan yang diperoleh dari hasil 
produksi bawang putih di Desa Fatuneno dan Desa Noepesu sebesar Rp. 534.429.503/Musim Tanam.

\subsection{Analisis SWOT}

\begin{tabular}{|c|c|c|}
\hline EFE & 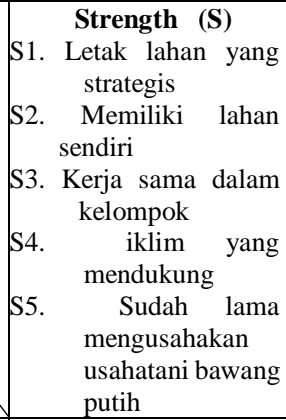 & 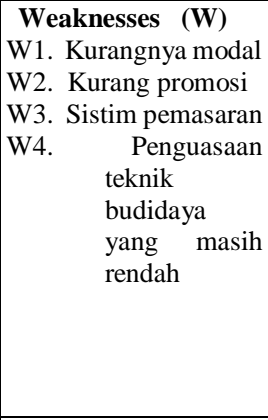 \\
\hline $\begin{array}{l}\text { Opportunities (O) } \\
\text { O1. Dukungan dari } \\
\text { PEMDA } \\
\text { O2. Kondisi lingkungan } \\
\text { yang mendukung } \\
\text { O3. Permintaan pasar } \\
\text { selalu ada } \\
\text { O4. Daya } \\
\text { penyimpanannya } \\
\text { yang tahan lama } \\
\text { O5. Eban merupakan } \\
\text { sentral/pusat } \\
\text { produksi bawang } \\
\text { putih }\end{array}$ & $\begin{array}{l}\text { Strategi S-O } \\
\text { Meningkatkan } \\
\text { produksi bawang } \\
\text { putih, membangkitkan } \\
\text { semangat petani,pihak } \\
\text { pemerintah } \\
\text { memberikan bantuan } \\
\text { penyuluhan sehingga } \\
\text { usahatani bawang } \\
\text { putih terus berlanjut } \\
\text { agar memenuhi } \\
\text { permintaan pasar yang } \\
\text { lebih luas. }\end{array}$ & \begin{tabular}{l}
\multicolumn{1}{c}{ Strategi W-O } \\
Meningkatkan \\
keterampilan dalam \\
pemasaran, \\
meningkatkan \\
kualitas produk, serta \\
meningkatkan dan \\
memperkuat promosi \\
di bidang teknologi \\
informasi melalui \\
(media cetak, \\
elektronik maupun \\
internet).
\end{tabular} \\
\hline $\begin{array}{l}\text { Threats }(\mathbf{T}) \\
\text { T1. Persaingan produksi } \\
\text { bawang putih dari } \\
\text { luar Eban } \\
\text { T2. Harga bawang yang } \\
\text { tidak stabil } \\
\text { T3. Serangan hama } \\
\text { T4. Sarana dan prasarana } \\
\text { transportasi yang } \\
\text { tidak mendukung }\end{array}$ & $\begin{array}{l}\text { Strategi (S-T) } \\
\text { Kekuatan yang ada } \\
\text { pada petani bawang } \\
\text { putih adalah kerja } \\
\text { sama dalam kelompok } \\
\text { tani dan mempunyai } \\
\text { lahan sendiri lebih } \\
\text { mmemperkuat untuk } \\
\text { mengantisipasi } \\
\text { ancaman persaingan } \\
\text { bawang sejenis dari } \\
\text { luar Eban dan harga } \\
\text { bawang putih yang } \\
\text { tidak setabil agar } \\
\text { harga bawang putih di } \\
\text { pasaran menjadi stabil. }\end{array}$ & \begin{tabular}{lr}
\multicolumn{2}{c}{ Strategi (W-T) } \\
Meningkatkan modal \\
serta perhatian \\
pemerintah $r$ dalam \\
penyediaan & sarana \\
dan prasarana \\
transportasi agar dan \\
pemberian \\
penyuluhan dalam hal \\
pemasaran \\
mendapatkan \\
$\begin{array}{lr}\text { pemasaran } \\
\text { efisien. yang }\end{array}$
\end{tabular} \\
\hline
\end{tabular}

Berdasarkan Tabel 4 pada Matriks SWOT maka didapatkan 4 langkah strategi yaitu sebagai berikut :

\section{Strategi $\mathbf{S}-\mathbf{O}$}

Strategi ini didapatkan dengan memanfaatkan dan memaksimalkan kekuatan yang dimiliki oleh petani untuk mengambil atau memanfaatkan peluang yang ada. Berdasarkan hasil analisis di peroleh beberapa strategi berikut : letak lahan yang strategis, memiliki lahan sendiri, kerjasama antar petani, iklim yang mendukung dan sudah lama berusahatani bawang putih untuk memperoleh peluang dan dukungan dari PEMDA dalam hal memberikan penyuluhan pada petani bawang putih agar meningkatkan hasil produksi bawang putih sehingga permintaan pasar yang ada selalu terpenuhi. Kerja sama antar petani di eban mampu meningkatkan produksi bawang putih sehingga dapat meningkatkan pendapatan petani. Dengan melihat kekuatan yang ada pada petani bawang putih menjadi peluang dalam mengembangkan usahatani bawang putih. Pihak pemerintah dapat memberikan bantuan berupa penyuluhan dan pupuk untuk para petani sehingga usahatani bawang putih terus berlanjut dan dapat memenuhi permintaan pasar yang lebih luas.

\section{Strategi $\mathbf{S}-\mathbf{T}$}

Strategi ini didapatkan dengan memaksimalkan kekuatan yang dimiliki dalam mengantisispasi ancaman yang ada. Berdasarkan hasil analisis diperoleh beberapa strategi berikut : kekuatan yang ada di petani adalah letak lahan yang strategis dan iklim yang mendukung, memiliki lahan sendiri dan kelompok ini selalu bekerja sama dalam mengusahakan usahatani bawang putih dan aktif berdiskusi untuk kemajuan bagaimana meningkatkan produksi dan pemasaran bawang putih. Dan ini dapat di lihat, kerjasama diantara petani, iklim yang mendukung dan sudah lama berusahatani bawang putih dan lebih memperkuat untuk mengantisipasi ancaman persaingan bawang putih sejenis dari luar daerah eban dan meningkatkan jangkauan pemasaran yang luas agar harga bawang tidak berfluktuasi lagi. Dengan adanya dukungan dari PEMDA menjadi motivasi untuk terus melanjutkan usahatani bawang putih dan lebih memperluas lahan yang ada untuk berusahatani bawang putih. Selain letak lahan yang strategis dan mempunyai lahan sendiri diperlukan adanya pengalaman dalam berusahatani bawang putih, mempunyai lahan sendiri dan kondisi lingkungan yang mendukung bisa memenuhi permintaan pasr yang di inginkan. Pengalaman usahatani bawang putih yang dimiliki adalah selalu berusahatani bawang putih sehingga dapat memenuhi permintaan pasar dan usahatani bawang putihnya berkembang dengan baik dan dan dengan kerjasama yang baik anatar petani juga dapat membangkitkan semangat dalam berusaha bawang putih. Kebersamaan yang ada dalam petani ini dilakukan mulai dari budidaya sampai ke pemasarannya.

\section{Strategi W- O}

Strategi ini didapatkan dengan usaha meminimalisasikan kelemahan yang dimiliki untuk memanfaatkan peluang yang ada saat ini. Berdasarkan hasil analisis diperoleh beberapa strategi berikut ini :

Kelemahan yang ada adalah kurangnya modal, kurang promosi, sistim pemasaran, penguasaan teknik budidaya yang masih rendah yang dimiliki dalam berusahatani bawang putih dengan menggunakan strategi $\mathrm{W}-\mathrm{O}$ maka perlu mendapatkan perhatian dari pemerintah dalam berusahatani bawang putih dengan memberi bantuan berupa modal, penyuluhan dan pelatihan khusus bagi anggota kelompok tani Oelatfob sehingga dapat meningkatkan ketrerampil dalam pemasaran yang lebih luas .Untuk memperkecil kelemahan - kelemahan internal dapat memanfaatkan peluang - peluang eksternal sehingga dapa meningkatkan kualitas produk dan memperkuat promosi lingkup lokal, regional, dan nasional melalui pemanfaatan kemajuan di bidang teknologi informasi (melalui media cetak, elektronik, maupun internet).

IV. Strategi W - T

Strategi ini didapatkan melalui usahatani bawang putih meminimalisasi kelemahan yang dimiliki untuk mengantisipasi ancaman atau untuk menghadapi kemungkinan dan ancaman yang berada diluar eksternal. Berdasarkan hasil analisis diperoleh beberapa strategi berikut : meningkatkan terampil dalam pemasaran untuk dapat bersaing dengan usahatani bawang putih sejenis dari luar daerah Eban dan meningkatkan promosi untuk jangkauan pemasaran yang lebih luas. Kelemahan yang ada di petani bawang putih adalah dalam pemasaran yang masih rendah dan perlu mendapat perhatian dari pemerintah dalam meningkatkan ketrampilan dalam pemasaran yang lebih luas. Selama ini petani blm pernah melakukan promosi baik melalui media cetak, elektronik, maupun internet, promosi yang dilakukan selama ini hanya melalui mulut ke mulut atau menawarkan secara langsung ke pembeli/pemborong. Padahal dengan kapasitas usahatani bawang putih yang ada dapat memenuhi permintaan pasar dan dapat meningkatkan promosi dan memperluas jangkauan pemasaran yang lebih luas lagi.

\section{Simpulan}

Berdasarkan hasil penelitian dan analisis Pendapatan Usahatani Bawang

Putih di Desa Fatuneno dan Desa Noepesu, maka penulis menyimpulkan bahwa:

1. Gambaran Keragaan usahatani bawang putih di Kecamatan Miomaffo Barat mulai dari Pengolahan lahan, Persiapan bibit, Penanaman, Pemeliharaan, panen, pasca panen dan pemasaran.

2. Umbi yang digunakan dalam penelitian sebanyak $4.5 \mathrm{~kg}$. Rendemen minyak yang diperoleh sebanyak $4.5 \mathrm{~mL}$. Rendemen minyak yang diperoleh adalah $1 \%(\mathrm{v} / \mathrm{b})$.

3. Secara bersama-sama nilai uji $\mathrm{f}(146.723)>$ dari nilai Ftabel (2.54) dengan demikian dapat disimpulkan secara statistik dapat dibuktikan bahwa semua variabel independen faktor luas lahan, benih, tenaga kerja, pengalaman, dan pendidikan secara bersama-sama (simultan) berpengaruh nyata pada produksi usahatani bawang putih. sedangkan secara sendiri-sendiri (parsial) faktor luas lahan, benih, tenaga kerja, pengalaman, dan pendidikan berpengaruh secara nyata terhadap produksi usahatani bawang putih. Uji t luas lahan (2.186) > t tabel(1.63), uji t benih (2.116) $>\mathrm{t}$ tabel (1.63), uji $\mathrm{t}$ tenaga kerja $(0.261)<\mathrm{t}$ tabel $(1.63)$, uji t pengalaman $(0.620)<\mathrm{t}$ tabel $(1.63)$, dan uji t pendidikan $(0.726)<\mathrm{t}$ tabel $(1.63)$.

4. Berdasarkan hasil penelitian usahatani bawang putih di Desa Fatuneno dan Desa Noepesu Kcamatan Miomaffo Barat Kabupaten Timor Tengah Utara dengan luas lahan sebesar 8,827 are dan rata-rata produksi setiap tahun sebesar $151 \mathrm{Kg} /$ Musim tanam, maka pendapatan petani di Desa Fatuneno dan Desa Noepesu sebesar Rp. Rp. 534.429.503/Musim tanam.

5. Berdasarkan grafik analisis SWOT titik koordinat 0,10 dan 1,07 berada pada kuadran I (Agresif) yang berarti posisi ini menandakan bahwa situasi dalam usahatani bawang putih menguntungkan, petani bawang putih memilik peluang dan kekuatan sehingga dapat memanfaatkan peluang yang ada Sesuai matriks SWOT di peroleh 4 strategi utama yang dilakukan berdasarkan matriks SWOT antara lain : 1) strategi SO : kekuatan yang dimiliki adalah letak lahan yang strategis, memiliki lahan sendiri, kerjasama dalam kelompok, iklim yang mendukung dan sudah lama berusahatani bawang putih dan untuk memperoleh peluang yang ada harus ada dukungan dari PEMDA, kondisi lingkungan yang mendukung, permintaan pasar yang selalu ada, daya penyimpanannya yang tahan lama dan eban merupakan sentral/pusat produksi bawang putih di wilayah TTU. 2) strategi WO : meningkatkan modal pada kelompok tani Oelatfob untuk berusahatani bawang putih, kurang promosi, sistim pemasaran dan penguasaan teknik budidaya yang masih rendah harus segera diatasi dengan pelayanan yang lebih baik dari pemerintah daerah untuk lebih membuka peluang dan memenuhi permintaan pasar yang lebih luas lagi. 3) Strategi ST : kekuatan yang ada adalah letak lahan yang strategis, memiliki lahan sendiri, kerja sama dalam kelompok, iklim yang mendukung dan sudah lama mengusahatani bawang putih lebih di perkuat untuk untuk mengantisipasi 
ancaman persaingan bawang sejenis dari luar daerah Eban. 4) Strategi WT : meningkatkan modal yang di miliki petani untuk dapat bersaing deengan usahatani bawang putih sejenis lainnya dari luar daerah Eban dan meningkatkan promosi untuk jangkauan pemasaran yang lebih luas lagi.

Pustaka

BPS Kabupaten TTU, 2015. Timor Tengah Utara Dalam Angka, Kefamenanu

Harborne. 1996. Metode Fitokimia : Penuntun Cara Modern Menganalisis Tumbuhan. Terbitan Kedua. Terjemahan : K. Padmawinata dan I. Soediro Bandung : Penerbit ITB

Harun Nur Rasyid, 2004. Ensiklopedi Makanan Tradisional Indonesia (Sumatera). Direktorat Jenderal Kebudayaan

Soekartawi. 1995. Ilmu Usahatani dan Penelitian untuk Pengembangan Petani Kecil. UI. Press Jakarta.

Rangkuti, F., 2003. Analisis SWOT Teknik Pembedahan Kasus Bisnis. Penerbit PT Gramedia Pustaka Utama, Jakarta. 